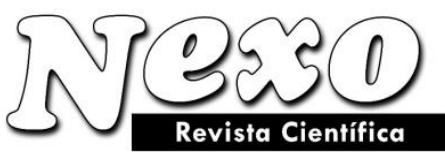

Vol. 34, No. 02, pp. 790-806/Junio 2021
ISSN-E 1995-9516

Universidad Nacional de Ingeniería COPYRIGHT @ (UNI). TODOS LOS DERECHOS RESERVADOS

http://revistas.uni.edu.ni/index.php/Nexo https://doi.org/10.5377/nexo.v34i02.11567

\title{
The impact study of the role of job rotation system effectiveness on work enthusiasm
}

\section{El estudio de impacto del papel de la eficacia del sistema de rotación de puestos en el entusiasmo laboral}

\author{
Massoud Ghaffari ${ }^{1}$, Seyed Rasoul Aghadavood ${ }^{2 *}$, Mohammad Reza Dalvi ${ }^{2}$ \\ ${ }^{1}$ Faculty of Management, Instiute of Higher Education Noure Hedayat (Non- Government \\ University), Shahrekord, Iran. \\ ${ }^{2}$ Department of Management, Dehaghan Branch, Islamic Azad University, Dehaghan, Iran. \\ *rasool_aghadavood@yahoo.com
}

(recibido/received: 12-enero-2021; aceptado/accepted: 08-abril-2021)

\begin{abstract}
In today's world, human capital is considered as the highest and most valuable asset of an organization, which affects the profits and losses of any company. The organizations that exist in these societies must be able to utilize human resources effectively. Job rotation is one of the management measures in the field of human resource management. It can create a creative, ideal, and secure organization that ensures commitment, knowledge transfer, skills acquisition, innovation, creativity, experience, job satisfaction, enthusiasm, exhaustion reduction, and human capital growth. The aim of this study is to investigate the effect of job rotation system on work motivation (studied in the region of two gas transfer operations). The present study is a correlation from the field and in terms of purpose and nature of application and in terms of descriptive-survey method and in terms of cross-sectional time. The statistical population of the study is 850 personnel (managers, experts and employees) of the region of two gas transmission operations. Using Cochran's formula, the sample size for limited communities is 285 people. The statistical population of the study consists of heterogeneous groups (formal and informal forces, managers and employees) using stratified random sampling method. In order to collect data, a researcher-made questionnaire with 20 items and a standard job motivation questionnaire with 17 items were used. The questionnaire is divided based on a five-point Likert scale. Reliability and validity were calculated and the value of 0.881 was obtained, which indicates the appropriate reliability of the questionnaires. To investigate the relationship and research hypotheses, Pearson correlation coefficient and regression, SPSS software and LISREL software were tested. The results show that the dimensions of job rotation such as human capital development and changes in human capital are related to work enthusiasm. Pearson correlation coefficient is 0.842 and 0.368 , respectively, which indicates a good correlation. Also, the development and changes of human capital have a significant effect on job motivation and the standard beta value was 0.343 and 0.281 , respectively, and all research hypotheses have been confirmed.
\end{abstract}

Keywords: job rotation, human capital development, changes in human capital, work enthusiasm 


\section{RESUMEN}

En el mundo actual, el capital humano es considerado como el activo más alto y valioso de una organización, lo que afecta las ganancias y pérdidas de cualquier empresa. Las organizaciones que existen en estas sociedades deben poder utilizar los recursos humanos de manera eficaz. La rotación de puestos es una de las medidas de gestión en el campo de la gestión de recursos humanos. Puede crear una organización creativa, ideal y segura que garantice el compromiso, la transferencia de conocimientos, la adquisición de habilidades, la innovación, la creatividad, la experiencia, la satisfacción laboral, el entusiasmo, la reducción del agotamiento y el crecimiento del capital humano. El objetivo de este estudio es investigar el efecto del sistema de rotación laboral sobre la motivación laboral (estudiado en la región de dos operaciones de transferencia de gas). El presente estudio es una correlación desde el campo y en términos de propósito y naturaleza de aplicación y en términos de método de encuesta descriptiva y en términos de tiempo transversal. La población estadística del estudio es de 850 personas (gerentes, expertos y empleados) de la región de dos operaciones de transmisión de gas. Usando la fórmula de Cochran, el tamaño de la muestra para comunidades limitadas es de 285 personas. La población estadística del estudio consta de grupos heterogéneos (fuerzas formales e informales, gerentes y empleados) utilizando el método de muestreo aleatorio estratificado. Para la recolección de datos se utilizó un cuestionario elaborado por un investigador con 20 ítems y un cuestionario estándar de motivación laboral con 17 ítems. El cuestionario se divide en base a una escala Likert de cinco puntos. Se calculó confiabilidad y validez y se obtuvo el valor de 0.881 , lo que indica la adecuada confiabilidad de los cuestionarios. Para investigar la relación y las hipótesis de investigación, se probaron el coeficiente de correlación y regresión de Pearson, el software SPSS y el software LISREL. Los resultados muestran que las dimensiones de la rotación laboral como el desarrollo del capital humano y los cambios en el capital humano están relacionadas con el entusiasmo laboral. El coeficiente de correlación de Pearson es 0,842 y 0,368, respectivamente, lo que indica una buena correlación. Además, el desarrollo y los cambios del capital humano tienen un efecto significativo en la motivación laboral y el valor beta estándar fue 0.343 y 0.281 , respectivamente, y todas las hipótesis de investigación han sido confirmadas.

Palabras clave: rotación laboral, desarrollo del capital humano, cambios en el capital humano, entusiasmo laboral.

\section{INTRODUCTION}

What is important for human resource development is that the enhancement of human resources not only is reached through technical and specialized training, but also the development of personnel's training in different ways, and this method will not be successful without implementing strategic plans in the field of human resource management. The job rotation system, which saves time, costs and better performance is one of the two role mechanisms that both eases the organization's managerial affairs and leads to the development of human resources. Also, it cultivates human resources in various dimensions. Job rotation is a method to turn members who are partial and limited to into holistic individuals that see and understand problems on a larger scale. It is a process that employees of an organization at different levels of the family, work in a shift manner. So, job rotation means replacing duties between persons or employees for increasing motivation and enthusiasm in their workplace. In organizations, the director of the organization assigns different duties and responsibilities to the members in different time periods and in proportion to the activities and programs of the organization, in order to provide a ground for the person to get acquainted with other activities and discover their talents and skills. 
Nowadays, the job rotation's method is called cross training. Job rotation is an aspect of training in an organization that includes managers and employees. In order to achieve its lofty goals, providing optimal services at the community level, the region needs two managers and employees to perform their duties in the best way and show commitment and dependence. Employees are considered as human resources that they are one of the most important value-creating factors in the organization. These factors lead enhance the organization to continue its survival, prevent its decline and achieve development, progress. The results of this study can improve the development plans of two gas transmission operations in the region and be effective in the productivity of the organization for the quantitative and qualitative growth of the personnel of the region two gas transmission operations. So, it can be concluded that "improving the quantitative and qualitative conditions of the organization" is the most important achievement. Examining and recognizing the effect of job rotation on employees' work enthusiasm in the region of two gas transmission operations in order to reap its benefits for the community, can well justify the present research problem. The importance and necessity of the present study can be examined from three dimensions: Theoretical dimension, information vacuum dimension and operational dimension. Each one is addressed separately. In terms of theoretical dimension, it can be said that: What important for human resource development is that human resource improvement only with training Technical and specialized is not achieved, but personnel training should be developed in various ways, and this will not be possible except by implementing strategic plans in the field of human resource management.

Today, formal training alone cannot develop organizational people in different dimensions. This is because many capabilities and qualities of human resources are developed in practice. Also, one of the most effective ways to expand the horizons of employees is the job rotation. The two role mechanisms facilitate the executive affairs of the organization that leads to the development of human resources. It is considered as the system of rotation in jobs, which saves time, costs and better work and cultivates human resources in various dimensions. Job rotation is usually used as a development technique. In terms of theoretical vacuum, it is stated as follows:

According to the researcher's studies in the field under study, so far, no research has been found in the country that examines job rotation from two dimensions of human capital development and changes in human capital on employees' work enthusiasm in relation to each other. There is a research vacuum in this field that will be addressed in this research and will definitely lead to literary richness in this field. This is also the difference between the present study and previous researches, the results of which will be considered as the innovation of this research.

Operationally, it can also be stated that:

The study of such a study is necessary for the study population (the second district of gas transmission operations) which is located in three provinces of Isfahan, Chaharmahal, Bakhtiari and Kohgiluyeh and Boyer Ahmad and the researcher hopes that by conducting this study, the results will be presented to Zone 2 gas transmission managers have the following achievements:

1) The gas transmission managers of the second district, need to gain more and more knowledge about the concepts, job rotation, as well as their importance and role in the effectiveness of the organization.

2) The gas transmission managers of the second district and relevant officials should be aware of the job rotation status and take the necessary steps to improve it. 
3) The second district of gas transmission, by recognizing the factors affecting the job rotation, try to take actions and behaviors that lead to increasing and improving the rotation situation, and vice versa, avoid, actions and behaviors that lead to reducing job satisfaction in the job rotation.

4) The second district of gas transmission, if they wish, they can use the job rotation measurement tool presented in this study to personally assess the job rotation of employees and, of course, the level of work enthusiasm and, consequently, their productivity.

5) Considering that the region, like other subsidiaries of the Ministry of Petroleum, has considered the issue of job rotation in order to increase the commitment and skills of human resources to reduce costs, savings and the development of the organization, it is necessary that The problem of the effectiveness of the job rotation system on work motivation should be studied.

\section{THEORETICAL FOUNDATIONS AND RESEARCH BACKGROUND}

\subsection{The Job Rotation, Human Resource Improvement Technique (Job Path)}

Job rotation is also one of the most important types of training, because in advanced organizations it is believed that the quality level of personnel is the most important factor for success and this is reached through on-the-job training. For example, in Japanese institutions on-the-job training is used as a job rotation technique. It is the main axis of training managers and is not given much importance to training outside the workplace. This training is done through transfer to different jobs and is the most common and logical way to improve human resources.

In this method, the transfer of people in different jobs in one part is done according to the schedule under the title (career path), during which the employee learns the basic skills in each job and becomes an expert in that job, is transferred again and transferred. And it lasts until the person becomes familiar with other horizontal occupations of the same level and moves horizontally. After this stage, people are transferred from one part to another. Obviously, the job rotation in these steps is different for each type of career path and allocates different time to itself. In Japanese organizations, usually when the transfer and job rotation ends, the person reaches the age of 40 , and from now on, using the experiences gained from working in different jobs and the specialties and skills acquired, the manager is considered valuable to the organization. Job rotation is recommended in organizations around the world, but the reason for the success of this technique in countries like Japan is that the managers of such organizations have their manpower in lifelong employment and understand well that the training is designed to nurture them and Hence, they do not resist it. In fact, one of the benefits of job rotation at management levels can be considered the transformation of expert managers into holistic managers. For the development of job management, approaches such as horizontal job expansion, development, job deepening, enrichment, review of team-based activities, and finally the job rotation approach can be effective. The components of the development of road management with a new approach to personnel training are:

\section{A- Development at work}

Through training, consulting, coaching, performance appraisal systems, etc.

B- Development through work experiences:

Through job rotation, job enrichment, work teams, succession planning, talent and succession development, hands-on learning and work outside the organization.

C- Development through formal education by internal and external methods, tools and facilities. 
D. Development through self-promoting structuring.

\subsection{Work Enthusiasm}

Interest in working enthusiasm grew at the heart of exhaustion research. In the study of exhaustion, researchers gradually became interested in its opposite and positive side, namely job desire. After a quarter of a century of studying wear and tear, the logical question was what do we know about the other side of the coin? And in particular, can we find employees who work hard and are deeply involved in their work and drown in it? And if so, what drives them in this direction? Are there factors similar to what causes employee exhaustion? What are the effects of passion? How can it be increased? And finally, what psychological processes are related to this concept? With questions like these, researchers began to examine the opposite pole more regularly at the turn of the century. This coincided with the emergence of what the positivist psychological movement was emphasizing. Today's organizations want their employees to be motivated, creative, responsible, and involved in their work. Instead of doing their personal work (duty), employees are expected to be a few steps ahead. Of course, those who suffer from exhaustion do not have the ability to do so, but those who do not suffer from exhaustion may work much harder. The traditional negative approach is not going anywhere here and a new and positive approach is needed.

In this regard, job motivation not only plays a vital role in understanding positive organizational behaviors but also plays an important role in guiding human resource management and occupational health policies in organizations (Salanova and Shuffley, 2007: 55). Passion, which is usually symbolized in the concepts of marriage, is associated with active participation and total investment in the performance of the role. In the context of the workplace, passion has a more special meaning. These organizations reflect these interactions in the employment contract, in which employees provide services to the employer, commit to their job, and fulfill their employment obligations. By accepting and embracing their roles in the organization, employees spend energy on the plans and, in turn, become more and more absorbed in the plans they execute and become immersed in them.

\subsection{Research Background}

The research background related to the research title is briefly stated in Table (1):

Table 1. Research Background

\begin{tabular}{|c|c|c|c|}
\hline Row & $\begin{array}{c}\text { Researcher } \\
\text { of the Year }\end{array}$ & Title & Findings \\
\hline 7 & $\begin{array}{c}\text { Danesh- } \\
\text { Zadeh and } \\
\text { Abedi (2018) }\end{array}$ & $\begin{array}{c}\text { Relationship between job } \\
\text { rotation and efficiency, } \\
\text { productivity and job } \\
\text { performance of Imam } \\
\text { Khomeini Relief } \\
\text { Committee's employees in } \\
\text { Mazandaran province }\end{array}$ & $\begin{array}{c}\text { There is a significant relationship between job } \\
\text { rotation and employee productivity and } \\
\text { productivity. }\end{array}$ \\
$\begin{array}{c}\text { The relationship between job rotation and } \\
\text { employee performance was not significant. Also, } \\
\text { the relationship between job rotation and } \\
\text { efficiency, productivity and job performance of } \\
\text { personnel is different in terms of priority. }\end{array}$ \\
\hline 8 & $\begin{array}{c}\text { Mahmoudi } \\
\text { Aval \& } \\
\text { colleagues } \\
\text { (2018) }\end{array}$ & $\begin{array}{c}\text { Investigating the } \\
\text { effectiveness of job rotation } \\
\text { on the level of personnel } \\
\text { productivity in Mashhad } \\
\text { Water and Sewerage }\end{array}$ & $\begin{array}{c}\text { The results of this study showed that job rotation is } \\
\text { related to the level of personnel productivity and } \\
\text { all the hypotheses of this study were confirmed. }\end{array}$ \\
\hline
\end{tabular}




\begin{tabular}{|c|c|c|c|}
\hline Row & $\begin{array}{l}\text { Researcher } \\
\text { of the Year }\end{array}$ & Title & Findings \\
\hline & & Company & \\
\hline 11 & $\begin{array}{l}\text { Rostam } \\
\text { Zadeh } \\
\text { Moradi } \\
\text { \& Berenj } \\
\text { Abaadi }\end{array}$ & $\begin{array}{l}\text { The effect of job rotation on } \\
\text { the productivity of the } \\
\text { employees of Sepah Bank } \\
\text { branches in Mako Free } \\
\text { Trade and Industrial Zone }\end{array}$ & $\begin{array}{l}\text { Job rotation and its dimensions affect the } \\
\text { productivity of employees of Sepah Bank branches } \\
\text { and among the dimensions of job rotation, the } \\
\text { system and procedures have the greatest impact on } \\
\text { the productivity of employees of Sepah Bank } \\
\text { branches in Mako Free Trade and Industrial Zone. }\end{array}$ \\
\hline 16 & $\begin{array}{l}\text { Ibrahim } \\
\text { Zadeh } \\
(2017)\end{array}$ & $\begin{array}{l}\text { Evaluating the effectiveness } \\
\text { of job rotation system and } \\
\text { its effect on manpower } \\
\text { productivity Case study: } \\
\text { Ansar Bank, Urmia }\end{array}$ & $\begin{array}{l}\text { Job rotation system affects the productivity of } \\
\text { human resources of Ansar Bank employees in } \\
\text { Urmia city. Also, the effect of using the job } \\
\text { rotation system on the dimensions of employees' } \\
\text { capabilities (understanding or imagining the role, } \\
\text { organizational support, performance training and } \\
\text { feedback, valid legal actions, motivation or desire, } \\
\text { environmental appropriateness) has been tested. } \\
\text { The use of job rotation system has a positive and } \\
\text { significant effect on the productivity of human } \\
\text { resources so that the use of job rotation system has } \\
\text { a positive effect on employees' capability, clarity, } \\
\text { assistance, evaluation, credit, motivation and job } \\
\text { environment of Ansar Bank in Urmia. }\end{array}$ \\
\hline 17 & $\begin{array}{c}\text { Badilie } \\
(2015)\end{array}$ & $\begin{array}{l}\text { Investigating the mediating } \\
\text { role of organizational } \\
\text { commitment and job } \\
\text { satisfaction in the } \\
\text { relationship between job } \\
\text { rotation and the occurrence } \\
\text { of creative behavior; (Case } \\
\text { study: Part Rubber } \\
\text { Industrial Group) }\end{array}$ & $\begin{array}{l}\text { Findings of this study show that the relationship } \\
\text { between job rotation with job satisfaction and } \\
\text { organizational commitment is positive and } \\
\text { significant and job rotation due to job satisfaction } \\
\text { and organizational commitment has a positive } \\
\text { effect on the occurrence of creative behavior in the } \\
\text { study population. }\end{array}$ \\
\hline 18 & $\begin{array}{c}\text { Farhang, } \\
\text { Pourghaz } \\
\& \\
\text { Jamshid Zehi } \\
\text { (2014) }\end{array}$ & $\begin{array}{l}\text { The effectiveness of job } \\
\text { rotation and its relationship } \\
\text { with organizational justice } \\
\text { and organizational trust } \\
\text { among nurses of Zahedan } \\
\text { Social Security Hospital }\end{array}$ & $\begin{array}{l}\text { The effectiveness of job rotation among nurses of } \\
\text { Zahedan Social Security Hospital is relatively } \\
\text { desirable and organizational justice and trust are } \\
\text { acceptable. There is a direct and significant } \\
\text { relationship between the variable of job rotation } \\
\text { effectiveness with organizational justice and its } \\
\text { dimensions. There is a direct and significant } \\
\text { relationship between the effectiveness of job } \\
\text { rotation with organizational trust and the } \\
\text { dimensions of vertical trust and institutional trust. } \\
\text { But there is no significant relationship with the } \\
\text { horizontal trust dimension. There is a direct and } \\
\text { significant relationship between organizational } \\
\text { justice and organizational trust and their } \\
\text { dimensions. }\end{array}$ \\
\hline 20 & $\begin{array}{l}\text { Nazari } \\
(2013)\end{array}$ & $\begin{array}{l}\text { The role of job rotation and } \\
\text { performance of personnel in } \\
\text { health, educational and }\end{array}$ & $\begin{array}{l}\text { Personnel's performance increases with job } \\
\text { rotation, but job commitment, professional } \\
\text { affiliation, organizational affiliation, adherence to }\end{array}$ \\
\hline
\end{tabular}




\begin{tabular}{|c|c|c|c|}
\hline Row & $\begin{array}{l}\text { Researcher } \\
\text { of the Year }\end{array}$ & Title & Findings \\
\hline & & $\begin{array}{l}\text { treatment centers of Tabriz } \\
\text { University of Medical } \\
\text { Sciences }\end{array}$ & $\begin{array}{l}\text { work values, and employee participation have not } \\
\text { changed according to their job rotation. }\end{array}$ \\
\hline 21 & $\begin{array}{l}\text { Mahmodi } \\
\text { (2013) }\end{array}$ & $\begin{array}{c}\text { Investigating the } \\
\text { relationship between job } \\
\text { rotation and organizational } \\
\text { commitment of West } \\
\text { Azerbaijan Post Office } \\
\text { employees }\end{array}$ & $\begin{array}{l}\text { The results showed that there is a positive and } \\
\text { significant relationship between job rotation with } \\
\text { organizational commitment and emotional } \\
\text { commitment and duty commitment of postal } \\
\text { employees of West Azerbaijan province and the } \\
\text { relationship between job rotation and the three } \\
\text { dimensions of organizational commitment of } \\
\text { employees was confirmed. }\end{array}$ \\
\hline 22 & $\begin{array}{l}\text { Teybie } \\
\& \text { colleagues } \\
(2012)\end{array}$ & $\begin{array}{l}\text { Relationship between job } \\
\text { rotation and the } \\
\text { performance of the } \\
\text { personnel of the } \\
\text { environmental health unit of } \\
\text { Shahid Beheshti University } \\
\text { of Medical Sciences }\end{array}$ & $\begin{array}{c}\text { Job rotation is independent of the performance of } \\
\text { environmental health employees and there is no } \\
\text { significant relationship between job rotation and } \\
\text { employee performance. }\end{array}$ \\
\hline 23 & $\begin{array}{l}\text { Del-passand } \\
\text { \& colleagues } \\
\quad(2010)\end{array}$ & $\begin{array}{l}\text { The effect of job rotation on } \\
\text { exhaustion in nurses of } \\
\text { Kashani Hospital in Tehran }\end{array}$ & $\begin{array}{c}\text { Nurses ' exhaustion rate is moderate in terms of } \\
\text { personal performance and job rotation with the } \\
\text { current method has little effect on nurses' } \\
\text { exhaustion. }\end{array}$ \\
\hline 26 & $\begin{array}{l}\text { Al-khalidi } \\
\quad \& \\
\text { Abid Jasem }\end{array}$ & $\begin{array}{l}\text { The role of job rotation in } \\
\text { improving administrative } \\
\text { reform processes: An } \\
\text { analytical study from the } \\
\text { perspective of senior } \\
\text { managers at Al-Qadisiyah } \\
\text { University }\end{array}$ & $\begin{array}{l}\text { Helping the job rotation to develop performance } \\
\text { and strengthen the skills of senior leaders, as well } \\
\text { as resisting changes resulting from the belief that } \\
\text { the job belongs to the employee. In addition, one } \\
\text { of the main reasons for the failure of the } \\
\text { administrative reform process is that administrative } \\
\text { problems are dealt with independently of the } \\
\text { environment with which it communicates. It is } \\
\text { influenced by the administrative system. }\end{array}$ \\
\hline 30 & $\begin{array}{l}\text { Singh \& } \\
\text { colleagues } \\
(2013)\end{array}$ & $\begin{array}{l}\text { Reasons for using job } \\
\text { rotation }\end{array}$ & $\begin{array}{l}\text { The results showed that in addition to using } \\
\text { suitable clothing accessories for workers' ears } \\
\text { while working, the job rotation method can be used } \\
\text { to avoid injuries caused by physical work. }\end{array}$ \\
\hline 31 & $\begin{array}{l}\text { Chung \& } \\
\text { Gung } \\
(2013)\end{array}$ & $\begin{array}{l}\text { Human resource } \\
\text { management system } \\
\text { Flexibility, absorption } \\
\text { capacity, market } \\
\text { responsiveness and } \\
\text { corporate innovation }\end{array}$ & $\begin{array}{l}\text { Job rotation is necessary to have a human resource } \\
\text { management system. Because increasing the } \\
\text { breadth of knowledge and multi-skills of } \\
\text { employees, enables them to identify, absorb and } \\
\text { use new knowledge. Therefore, it is necessary for } \\
\text { companies with flexible human resource } \\
\text { management. These companies seek to increase } \\
\text { learning and knowledge to be flexible, and this is } \\
\text { also possible through rotation. }\end{array}$ \\
\hline
\end{tabular}

\subsection{Theoretical Framework of Research}


Job rotation is considered as one of the most effective ways to understand employee development. This is a job design concept that enables employees to train job skills and facilitate the job shape that is evoked during repetition of tasks. This is done with changes that tasks need. Previous research has also shown that when there is a correction of the appropriate relationship (for sampling and measurement errors), the average correlation between job rotation and job motivation was higher than 0.30 . In addition, the relationship between rotation and enthusiasm or satisfaction is higher even for complex jobs (e.g., professions) than for less complex jobs. Thus, contrary to previous studies, it seems that job enthusiasm is related to the development of human's capital in terms of job rotation. The Relationship is explained between changes in human's capital and work enthusiasm with rapid changes in human resource management and the need to encourage work enthusiasm. Moreover, it is an urgent and demanding necessity in the face of management as long as the organizations themselves are looking for a way out. In view of the changes it is witnessing, there seems to be a need for modern and new techniques, plans and tools to activate the human resource process, with job rotation being a useful tool for transmitting tactics within an organization. So, the potential is recognized by using job rotation to improve science and fidelity.

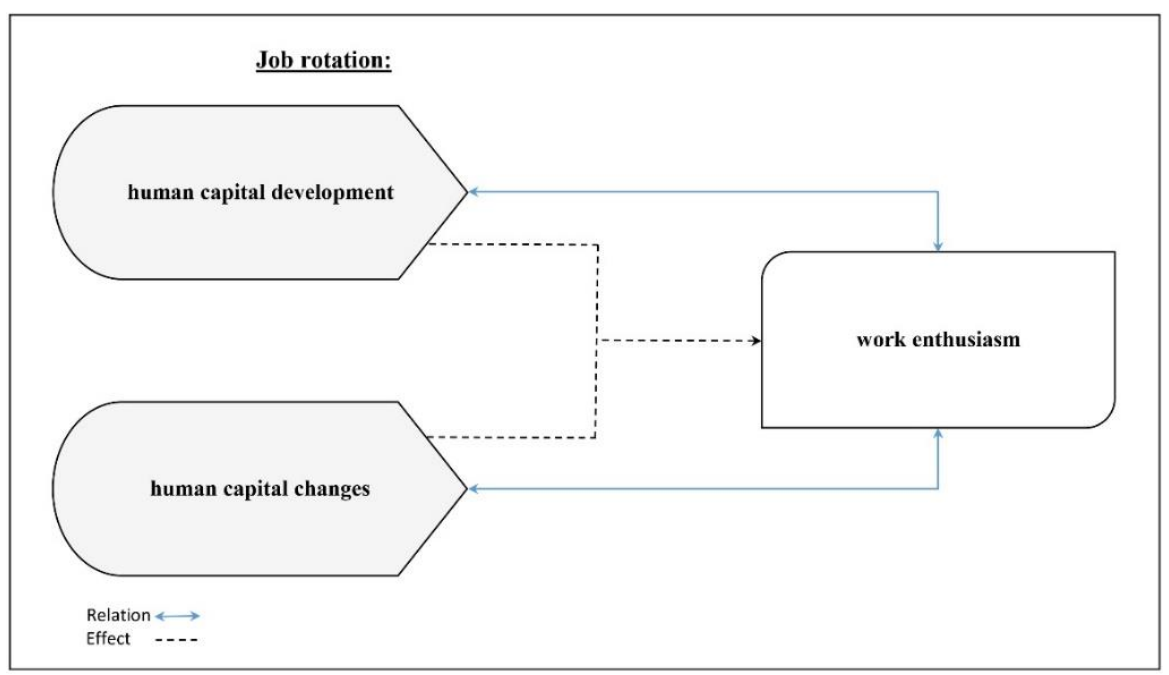

Figure 1 - Conceptual Model of (Jassim, 2018)

\section{Methodology}

This research is a correlational- field study and it is an applied study in nature. In addition, its' design is descriptive-survey and cross-sectional time.

\subsection{Participants}

The participants taking part in this study were 850 personnel (managers, experts and employees) of the region of two gas transmission operations in Isfahan, Chaharmahal and Bakhtiari and Kohgiluyeh and Boyer-Ahmad provinces. These provinces are subdivisions of region 2. A population of 1,700 employees work in region 2 gas transmission operations. It should be mentioned that restaurant staff and rental drivers are not included in this population.

The accurate sample size was calculated based on Cochran's formula and 285 employees were selected randomly because community work in this organization are heterogeneous including (formal and informal forces, managers and employees). 


\subsection{Data Collection Procedure}

Library information was used for collecting theoretical foundations data and the researcher designed a job rotation questionnaire with two dimensions (human capital development and human capital change). This questionnaire includes 20 items. In addition, the standard questionnaire of work enthusiasm by Salvanava and Shuffley (2001) including three dimensions (ability, commitment, absorption) with 17 items were used. The questionnaire was based on the Likert scale and its reliability was measured by Cronbach's alpha coefficient. The total reliability value was 0.881 and it presents the appropriate reliability and its validity was confirmed by experts.

\subsection{Data Collection Procedure}

The researcher took advantage of Pearson correlation coefficient, regression, and SPSS software for analyzing the data.

\section{RESULTS}

\subsection{Descriptive and Demographic Statistics}

Descriptive statistics were run to analyze demographic variables. Table 2 shows the result of 285 questionnaires that have been analyzed statistically.

Table 2: Demographic Information of Variables

\begin{tabular}{|c|c|c|c|}
\hline Variable & Range & Frequency & Frequency Percent \\
\hline \multirow{3}{*}{ Gender } & Female & 58 & 20.3 \\
\cline { 2 - 4 } & Male & 222 & 79.6 \\
\hline \multirow{4}{*}{ Age } & Less than 30 & 5 & 1.7 \\
\cline { 2 - 4 } & $31-40$ & 127 & 44.5 \\
\cline { 2 - 4 } & $41-50$ & 94 & 32.9 \\
\cline { 2 - 4 } & More Than 50 & 59 & 20.7 \\
\hline \multirow{4}{*}{ Education } & Diploma & 28 & 9.8 \\
\cline { 2 - 4 } & Associate Degree & 24 & 8.4 \\
\cline { 2 - 4 } & Bachelor of Degree & 122 & 44.5 \\
\cline { 2 - 4 } & Master of Art & 106 & 37.1 \\
\hline \multirow{3}{*}{ Types of Employment } & Permanent & 195 & 70.1 \\
\cline { 2 - 4 } & Direct Contract & 26 & 9.1 \\
\cline { 2 - 4 } & Indirect Contract & 59 & 20.7 \\
\hline \multirow{3}{*}{ Attendance to Work } & Day Work & 251 & 89.8 \\
\cline { 2 - 4 } & Shift Work & 10 & 3.5 \\
\cline { 2 - 4 } & Job Rotation & 19 & 6.6 \\
\hline Sum & & 285 & 100 \\
\hline
\end{tabular}

\subsection{Analysis of Inferential Findings}

\subsubsection{Kolmogorov-Smirnov Test}

In order to test the research hypotheses in terms of significance, first the distribution of scores in terms of normality is tested. The Kolmogorov-Smirnov test is used for this purpose. This test is used to specify whether a sample of a community follows a particular data distribution or not. 
Table 3: Results of Kalmogorov-Smirnov test

\begin{tabular}{|c|c|c|c|}
\hline Variable & Kalmogorov-Smirnov statistics & P & Normality status \\
\hline Human capital development & 0.067 & 3.157 & Confirmation of $\mathrm{H}_{0}$ \\
\hline Changes in human capital & 0.083 & 3.400 & Confirmation of $\mathrm{H}_{0}$ \\
\hline Job rotation & 0.078 & 4.105 & Confirmation of $\mathrm{H}_{0}$ \\
\hline Ability & 0.936 & 3.939 & Confirmation of $\mathrm{H}_{0}$ \\
\hline Commitment & 0.781 & 2.974 & Confirmation of $\mathrm{H}_{0}$ \\
\hline Attraction & 0.069 & 3.500 & Confirmation of $\mathrm{H}_{0}$ \\
\hline Work enthusiasm & 0.077 & 3.841 & Confirmation of $\mathrm{H}_{0}$ \\
\hline
\end{tabular}

The value of Sig for job rotation and the reform of administrative process is more than 0.05 . Therefore, $\mathrm{H}_{0}$ is accepted and confirms normal status of data.

\subsubsection{The First Sub-Hypothesis}

There is a significant relationship between human capital developments (from the dimensions of job rotation) and employees' work enthusiasm.

Table 4: Pearson correlation test of two variables between human capital development and work enthusiasm

\begin{tabular}{|c|c|c|}
\hline Independent variable & Dependent variable & Work enthusiasm \\
\hline \multirow{4}{*}{ Human capital development } & $\mathrm{R}$ & 0.842 \\
\cline { 2 - 3 } & $\mathrm{Sig}$ & 0.000 \\
\cline { 2 - 3 } & $\mathrm{a}$ & 0.05 \\
\cline { 2 - 3 } & $\mathrm{N}$ & 285 \\
\cline { 2 - 3 } & Result & Confirmation of $\mathrm{H}_{1}$ \\
\hline
\end{tabular}

As depicted in the above table, the values of $r=0.842$ and sig $=0.000$ are observed, so that null hypothesis, ie no significant relationship, is rejected and the first hypothesis is accepted. Therefore, a relationship between human capital development and employees' work enthusiasm. As shown in table 4, the significance level of the relationship between human capital development and employees' work enthusiasm is less than the 0.05 error level. Therefore, it is inferred that there is a significant correlation between the two variables. In addition, it is evident that there is a positive (direct) and significant relationship between human capital development (job rotation) and employees' work enthusiasm. Therefore, the first sub-hypothesis is confirmed.

\subsubsection{The second sub-hypothesis}

There is a meaningful relationship between changes in human capital (from the dimensions of job rotation) and employees' work enthusiasm.

Table 5- Pearson correlation test of two variables between changes in capital development and work enthusiasm

\begin{tabular}{|c|c|c|}
\hline Independent variable & Dependent variable & Work enthusiasm \\
\hline \multirow{4}{*}{ Changes in capital development } & $\mathrm{R}$ & 0.368 \\
\cline { 2 - 3 } & $\mathrm{Sig}$ & 0.000 \\
\cline { 2 - 3 } & $\mathrm{A}$ & 0.05 \\
\cline { 2 - 3 } & $\mathrm{N}$ & 285 \\
\cline { 2 - 3 } & Result & Confirmation of $\mathrm{H}_{1}$ \\
\hline
\end{tabular}

As depicted in the above table, the values of $\mathrm{r}=0.368$ and sig $=0.000$ are observed, so that null hypothesis, ie no significant relationship, is rejected and the first hypothesis is accepted. Therefore, a 
relationship between changes in human capital and employees' work enthusiasm. As shown in table 5, the significance level of the relationship between human capital development and employees' work enthusiasm is less than the 0.05 error level. Therefore, it is inferred that there is a significant correlation between the two variables. In addition, it is evident that there is a positive (direct) and significant relationship between human capital development (job rotation) and employees' work enthusiasm. Therefore, the second sub-hypothesis is confirmed.

The researcher took advantage of regression test was for testing the third and fourth sub-hypotheses. Obtained results are shown below:

\subsubsection{The third sub-hypothesis}

Human capital development (from the dimensions of job rotation) influences on employees' work enthusiasm.

Table 6- Results of linear regression between independent and dependent variables

\begin{tabular}{|c|c|c|c|c|c|}
\hline \multirow{2}{*}{ Variables } & $\begin{array}{c}\text { Non-Standard Co- } \\
\text { Efficient }\end{array}$ & Standard & \multirow{2}{*}{ T } & \multirow{2}{*}{ Sig } \\
\cline { 2 - 4 } & Boefficient & Beta & & \\
\hline Width of Origin (Constant) & 2.711 & 0.135 & - & 20.145 & 0.000 \\
\hline Human Capital Development & 0.144 & 0.38 & 0.343 & 3.832 & 0.000 \\
\hline
\end{tabular}

Independent variable: human capital development

Dependent variable: work enthusiasm

According to table 6, the significance level of the independent variable (human capital development) and the value of $\mathrm{T} 3.832$ equal to zero and less than 0.05 . Therefore, human capital development has a significant effect on work enthusiasm (0.144) ( $\mathrm{p}<0.05)$. Indeed, to that extent that standard deviation (SD) in the development of human capital increases, SD of work enthusiasm will increase by 0.144 .

4.2.4 The fourth sub-hypothesis

Changes in human capital can impose a significant effect on work enthusiasm.

Table 7- Results of linear regression between independent and dependent variables

\begin{tabular}{|c|c|c|c|c|c|}
\hline \multirow{2}{*}{ Variables } & $\begin{array}{c}\text { Non-Standard co- } \\
\text { Efficient }\end{array}$ & Standard & \multirow{2}{*}{ T } & \multirow{2}{*}{ Sig } \\
\cline { 2 - 4 } & B & SD & Betficient & & \\
\hline Width of Origin (Constant) & 2.484 & 0.130 & - & 19.057 & 0.000 \\
\hline Changes in Human Capital & 0.204 & 0.36 & 0.281 & 5.733 & 0.000 \\
\hline
\end{tabular}

Independent variable: changes in human capital

Dependent variable: work enthusiasm

As depicted in table 7, the significance level of the independent variable (changes in human capital) and the value of $\mathrm{T} 5.733$ equal to zero and less than 0.05 . Therefore, changes in human capital t has a significant effect on work enthusiasm (0.204) ( $p<0.05$ ). Indeed, to that extent that standard deviation (SD) in the changes of human capital increases, SD of work enthusiasm will increase by 0.204 . Therefore, it should be mentioned that changes in human development will increase employee's work enthusiasm.

4.3 Fitting the General Model of Research

The results of analyzing the research model are presented in Figure 2. The observed values in all cases is greater than 0.3 and indicates the acceptable correlation between the hidden variables and the observable 
variables. After identifying the correlation between variables, a t-test should be performed. T-test is run to evaluate the significance of the relationship between variables. The significance level is defined at 0.05 . If the amount of observed factor loads calculated by t-value is test less than 1.96, the relationship is not significant. Regarding results in Figure 2, the measurement indicators of each scale used at a confidence level of $5 \%$ is more than 1.96 which indicates significant correlations.

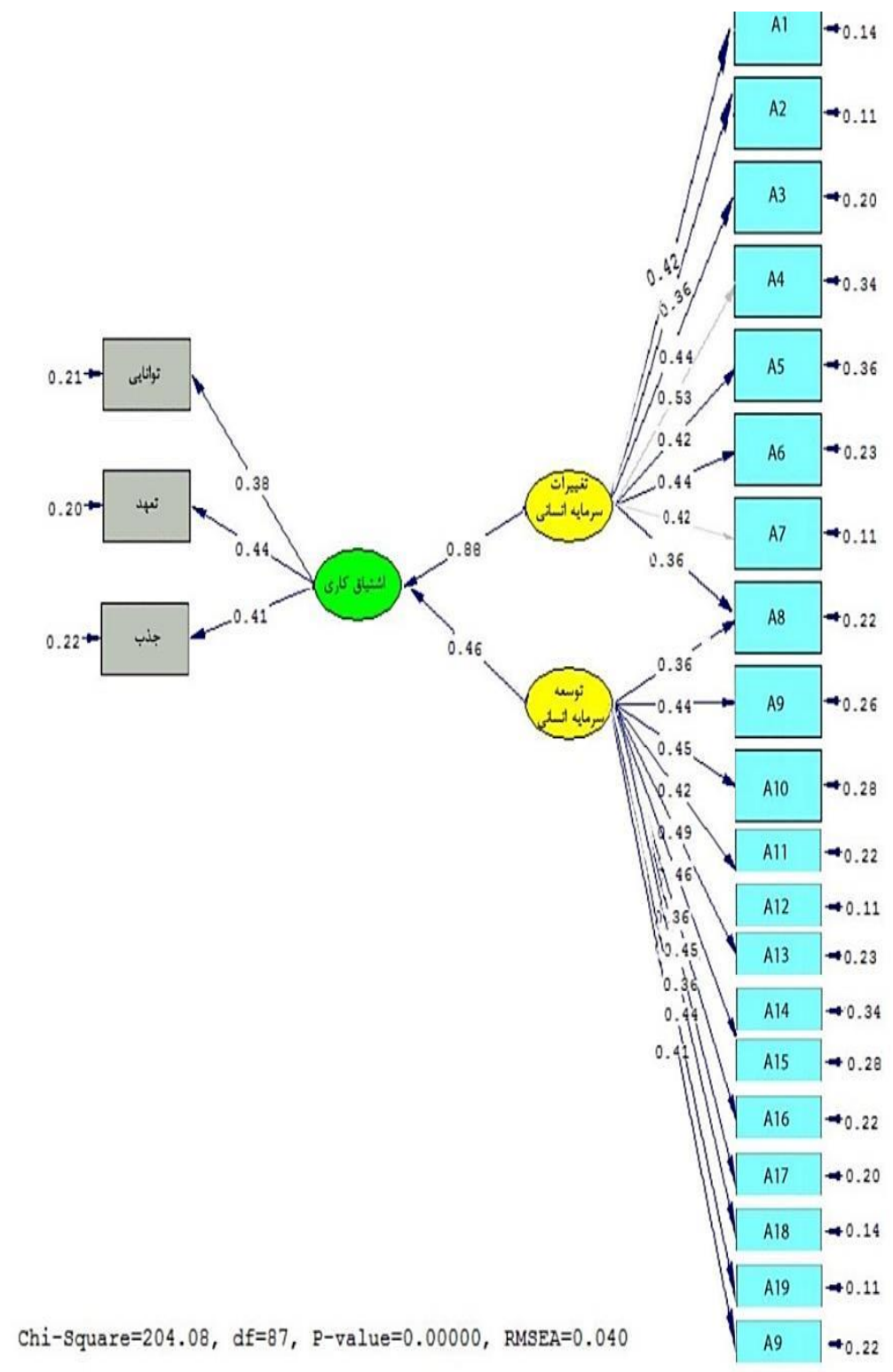

Figure 2 - Results of confirmation of the final model of the relationship between research variables

Table 8- The goodness indicators of the structural model fit of the research model

\begin{tabular}{|c|c|c|c|c|c|c|c|}
\hline Fitness Index & RMR & RMSEA & GFI & AGFI & NFI & NNFI & IFI \\
\hline Acceptable Values & $\leq 0.1$ & $\leq 0.1$ & $\geq 0.9$ & $\geq 0.9$ & $\geq 0.9$ & $\geq 0.9$ & $0 .-1$ \\
\hline Calculated Values & 0.061 & 0.040 & 0.93 & 0.96 & 0.94 & 0.97 & 0.89 \\
\hline
\end{tabular}




\section{DISCUSSION \& SUGGESTIONS FOR FURTHER STUDIES}

Job rotation as a common way requires employees to change their job for increasing their experiences. A lot of companies intend to have active employees working some activities to make their staffs have more mobility and interchangeability. The company need those employees providing company with more intelligence, creativity, and energy. The employee must be interested in changing jobs for learning new experiences and skills. In a creative and efficient organization, employees are not specializing in one area and have the opportunity to rotate their job for working in right position.

If job rotation is accompanied by promotion, it can satisfy employees and effect on their performance. When jobs are rotated, employees can feel significant change in their job, workplace, income, and their colleagues.

If these changes are as much or as much as people expect, will lead to increased job satisfaction as well as employee productivity. The effect of job rotation system on job motivation has been studied and according to the researcher's studies, no such study has been conducted in the country that examines both job rotation and job motivation variables. It can be said that one of the differences of this research is study of the mentioned variables was in the form of a model, which finally yielded the following results:

\subsection{First sub-hypothesis}

The results of this study showed that there is a relationship between human capital development (from the dimensions of job rotation) and employees' work enthusiasm. The relationship between human capital development and employees' work enthusiasm is less than at the 0.05 error level. Therefore, there is a significant correlation between the two variables. In addition, the correlation value between the two variables equals 0.842. Finally, using educational approach of the organization for developing and improving human resources in different units increased employees' work enthusiasm. This approach assist people viewing meticulously to change their view and observe the world and environment holistically. In addition to increasing the knowledge and experience of the individual in different jobs, it also reduces fatigue and emotional blame, and this leads to intellectual mobility, creativity and innovation. Also, the performance of a person in different positions and responsibilities will be a good criterion for evaluating and measuring his abilities. The result of this research is in line with researchers such as Van Wick, Stuarts and Mechanza (2019). They found that paying attention to job rotation and paying attention to key factors can have a positive effect on job satisfaction and ultimately work enthusiasm. These results are also in line with the results of Mehraban and Karami (1397). They also found in their research that there is a correlation between job rotation and job satisfaction and job satisfaction increases work motivation. Finally, the following suggestions are presented:

1. While considering this fact that the theoretical training needs, including basic, specialized and higher education in the gas company, as well as practical and in-person training requires time, money and separation from work, the training planners of the gas company should try to save on the time required to train and accelerate the creation of capabilities in the organization's manpower to teach part of the professional and practical training while employees are serving.

2 .One of the goals of the gas company is to develop the skills of the manpower and to develop the specialized capabilities of the employees. In addition, these employees should use the training workshops and, by giving more authority and power to the employees during the work, lead to independence and their freedom of action for creativity and innovation.

3 .The managers of the gas company must constantly gain experience and learn new materials in order to be more effective in making decisions. 
4 .In the gas company, it is better to promote employees based on meritocracy system as well as ability, commitment and experience, and to avoid selection subjectively, and make employees to have more commitment in the hope of progress based on rank.

5 .The managers of the gas company should encourage and appreciate the personnel in the presence of the public in order to increase the internal motivation of the employees.

\subsection{Second sub-hypothesis}

The results of this study showed that there is a relationship between changes in human capital (from the dimensions of job rotation) and employees' work enthusiasm. The relationship between changes in human capital and employees' work enthusiasm is less than at the 0.05 error level. Therefore, there is a significant correlation between the two variables. In addition, the correlation value between the two variables equals 0.368 . When a person in a job rotation system becomes responsible for a variety of jobs, there is no longer any place to attribute inadequacies and inefficiencies.

Employees become self-disciplined after working and receiving feedback in a structured way for some time. This allows the person to do their job well and have the least problems with the organization. In other words, using a practical approach to enrich and expand job concerns for employees leads to increased employees' work enthusiasm. The results of the study are in line with researchers such as Colinas et al. (2012). In their research, they concluded that they provide a number of practical implications for employees' work experience for job configuration. One of these factors can be job rotation, because job rotation requires the development of training and learning through relationships between managers, supervisors and employees with the aim of creating a learning bureaucracy and one of the ways that can increase employee satisfaction and work enthusiasm. These results are also in line with the results of Mehraban and Karami (1397). They also found in their research that there is a correlation between job rotation and job satisfaction. In addition, job satisfaction increases work enthusiasm. The following suggestions are provided:

1. Job rotation among managers of distinct departments or units of the gas company should not be done without prior background (lack of previous training and lack of awareness) and usually appointed bosses remove knowledgeable experts due to the fear of maintaining their position or consult with unknowledgeable people and cause damage to the organization.

2 .The manpower required by the research units should be done through the transfer of specialists in order to provide the staff of this department with enthusiasm and provide the required manpower for the research unit.

3. The managers of the gas company must be fully acquainted with the issues, problems and job descriptions of other parts of the organization.

4. If the staff fails to do the work and does not succeed, the managers of the gas company should identify the weaknesses and boosting strong points for the development of the organization in the future instead of determining the culprit.

\subsection{Third sub-hypothesis}

The third sub-hypothesis states that the development of human capital (from the dimensions of job rotation) imposed a significant effect on employees' work enthusiasm (confirmation). Therefore, the development of human capital to the extent of 19.2 has a significant effect on work enthusiasm with beta 
(0.343) ( $\mathrm{p}<0.05)$. In other words, to that extent standard deviation (0.343) (SD) increases in the development of human capital, the value of SD in work enthusiasm will increase by 0.343 standard deviation. One of the dimensions of a developed human being is that by internalizing motivations, expertise, ability and compassion, he / she donates everything to the goals of the organizations. The job rotation system is one of the mechanisms that solves the problem of monotony and routine of work, internalizes and sustains motivations. Indeed, employees are provided with learning opportunities to achieve various job skills for a certain period of time for increasing work enthusiasm. In other words, if repetitive tasks make employees bored and the employee's type of work is such that there is no rivalry, the employee can be rotated to another job at the same level of the organization that needs the same skills. But in this rotation, the ability of the individual to the relevant job should be checked to increase efficiency and the manager should avoid any biased approach, this will lead to increased employees' enthusiasm. The results of the study are in line with researchers such as Van Wick, Stuart, and Mechanza (2019) and the following suggestions are provided:

1. The criterion for encouraging employees to attend in the workplace for some hours (according to the costs it entails for the organization) should not be considered as doing more work, but based on the assignment and separation of employees' activities, even seemingly small in this regard, employees of departments Office, exploiters, etc., due to repetitive activity, have the most fatigue compared to other mission jobs.

2. The managers of the gas company should take action to create job security for their employees because the employees who are satisfied with their job and feel job security, work with internal motivation.

3. Creating responsibility and commitment instead of pure obedience: Some people consider themselves responsible and accountable because of their faith and purposefulness, and this is a good platform for managers who, with the right justification and training appropriate to the job, and then by delegating responsibility and authority increase their motivation.

4. Employees with pre-retirement experience should be temporarily appointed to a suitable position to encourage newly hired and young employees.

In order to maintain the order of the organization, hierarchy should be observed because it can damage the systemic relations of the organization and have negative factors such as increasing workload, low productivity at the output of the organization, and so on.

\subsection{Fourth sub-hypothesis}

The fourth sub-hypothesis states that changes in human capital (from the dimensions of job rotation) influences employees' work enthusiasm (confirmation). The results show that the development of human capital affected work enthusiasms. Therefore, changes in human capital have a significant effect on work enthusiasm with beta $(0.281)$ ( $\mathrm{p}<0.05)$. Regarding the positive of the standard beta, it is evident that by increasing SD in changes in human capital, this value for work enthusiasm will increase by 0.281 .

Indeed, it is observed can be concluded that changes in human development will increase employees' work enthusiasm. Nowadays, constant focus on the job by the individual is a sign of job stability which also leads to uniformity and repetition of jobs. Therefore, human research professionals use job rotation to move and familiarize human resources within the organization to motivate human resources and manage talent and succession. In other words, the use and application of job rotation in the organization motivates employees. Therefore, enthusiastic employees have a lot of energy and are more involved in the job. In other words, the employees who are rotated feel significant changes in their jobs, work environment, salary, and co-workers. If these changes are more or less than employees' expectation will lead to an 
increase in job motivation. The research results are in line with researchers such as Colinas et al. (2012) and it is suggested:

5. Managers of the gas company should review the attitudes and opinions of the heads of units before the rotation of employees.

6. Designing a job rotation system is a kind of structural change that the involved employees must be justified in order to adapt to it. Therefore, before implementing it, it is necessary for the management of the gas company to hold workshops or seminars to provide theoretical and practical training and to show the value of job rotation (which in addition to gaining job skills, does not transfer work-related fatigue to the family).

7. The managers of the gas company should form a group work and try to identify the jobs of the same family in all levels of the organization because it is usually useful to rotate in the jobs of the family so that people can use their experiences. In addition, factors such as similar activities, alignment of duties, levels of activities in terms of simplicity and complexity should be examined and the feasibility of implementing the rotation system in jobs should be carefully and expertly studied.

8 . Job rotation should be done among experts in departments or units similar to the gas company in order to process the on-the-job training process to train future managers (succession). In addition, in the case of appointment to managerial positions do not pay attention to only one unit in which they worked. It is better to keep their view to the whole units of the organization.

\section{CONCLUSION}

Job rotation reduces fatigue and monotony in simple jobs. Another advantage of this method is creating flexibility, intellectual mobility, creativity and innovation in the organization and training the workforce while also providing the workforce. The aim of this study was to investigate the effect of job rotation system on work motivation in the region of two gas transfer operations. The results show that the dimensions of job rotation such as human capital development and changes in human capital are related to work enthusiasm. Also, the development and changes of human capital have a significant effect on job motivation. According to the results, it can be concluded that job rotation is a good strategy to increase employee job motivation. Therefore, if this strategy is implemented purposefully, it will be useful for both employees and employers.

\section{REFERENCES}

Jassim, E. O. (2018). The Role of Job Rotation in Enhancing Administrative Reform Processes: An analytical Study of The Views of Senior Managers at Al-Qadisiyah University. Al-Qadisiyah Journal for Administrative and Economic Sciences, 20(1), 19-35.

Chang, S., Gong, Y., Way, S. A., \& Jia, L. (2013). Flexibility-oriented HRM systems, absorptive capacity, and market responsiveness and firm innovativeness. Journal of Management, 39(7), 1924-1951.

Daneshzadeh, M., \& Abedi Firoozjani, A. (2018). The relationship between job rotation and efficiency, productivity and job performance of Imam Khomeini Relief Committee staff, Mazandaran Province. Fifth National Conference on Applied Research in Management and Accounting, Tehran, Association Iran Management, 1-18. available at https://civilica.com/doc/784832.

Delpasand, M., Raeissi, P., Begdeli, F., \& Shahabi, M. (2011). The impact of job rotation on nurses burnout in Ayatollah Kashani hospital, Tehran: A case study. Iranian Occupational Health Quarterly, 7 (4), 7-17. 
brahimzadeh, Y. (2016). Evaluatng the effectveness of the job rotaton system and its impact on human resource productvity Case study: Ansar Bank, Urmia. 2nd Internatonal Conference on Research in Science and Technology, Turkey-Istanbul, Karin Insttute, 1-15.

Farhang, A., Pourghaz, A., \& Jamshid Zehi, S. (2014). The Effectiveness of job Rotation and it's Relationship with Organizational Justice and Organizational Trust". Management Researches, 7(23), 129-144.

Mahmoudi, F. (2013). Study of the relationship between job rotation and organizational commitment of the staff of the West Azerbaijan Post Office. International Conference on Management of Challenges and Strategies, Shiraz, 8-1.

Mahmoudi Aval, S. H., Khayat Moghadam. S., \& Erfanian Khanzadeh, H. (2018). Study of the effectiveness of job turnover on the level of employee productivity in Mashhad Water and Sewerage Company. 7th National Conference on Accounting and Management Applications, Tehran, Asia Golden Communication Group, 1-25. Mirsapasi, N. (2015). Strategic Management of Human Resources and Labor Relations (with a view to the trend of globalization). Tehran: Mir Publications.

Nazari, S. N. (1934). The role of job rotation and performance of staff in health, educational and medical centers of Tabriz University of Medical Sciences. Master Thesis, Islamic Azad University, Tabriz Branch.

Rostamzadeh, Y., \& Moradi Baranjabad, A. (2017). The effect of job rotation on employee productivity: a case study of Sepah Bank branches in Mako Free Trade and Industrial Zone. Fifth International Conference on Research Approaches in Humanities and Management, available at https://civilica.com/doc/824722.

Schaufeli, W. B., Bakker, A. B., \& Salanova, M. (2006). The measurement of work engagement with a short questionnaire: A cross-national study. Educational and psychological measurement, 66(4), 701-716.

Singh, L. P., Bhardwaj, A., \& Deepak, K. K. (2013). Occupational noise-induced hearing loss in Indian steel industry workers: An exploratory study. Human factors, 55(2), 411-424.

Soltani, I. (2018). Training human resource managers based on competency. Isfahan: Arkan Danesh Publications.

Soltani, I (2013). Cultivation of human capital. Isfahan: Arkan Danesh Publications.

Tabibi, S. J., Gohari, M. R., \& Fallahdar, H. (2012). The relationship between job rotation and performance of environmental health unit staff in the health centers of Shahid Beheshti University of Medical Sciences. Pajoohandeh Journal, 17(3), 121-126. 